Chirurgia (2017) 112: 477-481

No. 4, July - August

Copyright@ Celsius

http://dx.doi.org/10.21614/chirurgia.112.4.477

\title{
Diffuse Large B Cell Lymphoma in a Male Breast - A Rare Case Report
}

\author{
Adelina Birceanu Corobea ${ }^{1,3}$, Adrian Dumitrü ${ }^{2,3}$, Maria Sajin ${ }^{2,3}$, Radu Poenaru ${ }^{4}$, Ana Pușcașu ${ }^{4}$, Dragoș Chirita ${ }^{5}$, \\ Anca Evsei ${ }^{5}$
}

'Department of Pathology "Sf. Maria" Clinical Hospital, Bucharest, Romania 2Department of Pathology, Emergency Universitary Hospital, Bucharest, Romania

${ }^{3}$ Department of Pathology, "Carol Davila" University of Medicine and Pharmacy, Bucharest, Romania

${ }^{4}$ Research Center For Surgery and Liver Transplant,"Sf. Maria" Clinical Hospital, Bucharest, Romania ${ }^{5}$ CESITO Center, "Sf. Maria" Clinical Hospital, Bucharest, Romania

Corresponding author:

Adrian Dumitru, MD

Department of Pathology

Emergency Universitary Hospital

Bucharest, Romania

E-mail: eldarlight@yahoo.com
Received: 21.06 .2017 Accepted: 14.07 .2017

\section{Rezumat}

Limfomul difuz cu celulă mare B mamar la bărbat - prezentare de caz

Limfomul difuz cu celulă mare B mamar la bărbați reprezintă o entitate rară ce poate mima carcinomul mamar ca prezentare clinică, de aceea tratamentul inițial pentru majoritatea pacienților rămâne cel chirurgical. Diagnosticul şi tratamentul precoce complementar, chimioterapia şi radioterapia, sunt foarte importante. Vom prezenta cazul unui bărbat de 56 ani diagnosticat cu limfom difuz cu celulă mare B, primitiv cu localizare mamară - formațiune tumorală mamară fără limfadenopatie axilară. În urma biopsiei mamare, examenul histopatologic susținut de testele imunohistochimice stabilesc diagnosticul de limfom difuz cu celula mare B mare primitiv cu pozitivitate pentru CD 20, CD 10, şi negativitate pentru BCL 2, myc şi BCL 6 cu index de proliferare foarte mare (Ki 67 90\%). Pacientul a primit trei cure de chimioterapie R-CHOP (rituximab, ciclofosfamida, adriamicina, vincristine si prednisolon). Limfomul difuz cu celulă mare primitiv mamar la bărbat reprezintă o entitate foarte rară, fiind necesară o supiciune ridicată pentru diagnosticul şi tratamentul precoce.

Cuvinte cheie: limfom difuz cu celule mare B, sân, bărbat, tratament 


\begin{abstract}
Primary breast diffuse large B cell lymphoma (PBL) in male patients represents a rare clinical phenomenon and can imitate a breast carcinoma in its clinical presentation, so, therefore, the initial treatment for most patients remains surgery. Prompt diagnosis associating subsequent treatment combining chemotherapy and radiotherapy are of the utmost importance. We herein report a 56 year's old male patient diagnosed with diffuse large B cell lymphoma, after clinically presenting with a visible tumor in the left breast and showing no axillary lymphadenopathy. Following clinical diagnosis we performed a breast biopsy with subsequent immunohistochemistry testing. The results showed that the malignant cells stained positive for CD 20, CD 10, and negative for BCL 2, myc and BCL 6, ER/PR with a high proliferation index (Ki 67 90\%). The immunohistochemical tests were suggestive for primary large B cell lymphoma of the breast, germinal center type. The patient was submitted to three cycles of R-CHOP (cyclophosphamide, adryamicin, vincristine and prednisolone) and rituximab chemotherapy. Primary diffuse large $\mathrm{B}$ cell lymphoma is an extremely unique disease that involves a rather difficult differential diagnosis with a breast carcinoma. A strong index of clinical suspicion is necessary with early diagnosis and treatment.
\end{abstract}

Key words: diffuse large B cell lymphoma, breast, male, treatment

\section{Introduction}

Primary Non-Hodgkin malignant (NHML) lymphoma of the breast (PLB) is a very uncommon disease, subject to curability, with a very unusual occurrence in male patients. NHML stands for $2,2 \%$ of extranodal lymphomas and for 0,04 to $0,5 \%$ of malignant breast neoplasms $(1,2)$. Despite clinical and imagistic similarities between breast lymphoma and carcinoma, the overall prognosis differs regarding treatment options according to recent studies. Treatment modalities includes surgery, radiotherapy and chemotherapy used alone or in combination (3). Although all histological types of lymphoma have been described, PBLs are commonly B cell lymphomas; approximately one-half are diffuse large $B$ cell lymphoma (DLBCL) (4). There is insufficient information regarding $\mathrm{PBL}$ and especially DLBCL of breast in male patients.

\section{Case Report}

A 56 year old man showed up with a mass in the breast and he was diagnosed with primitive breast diffuse large cell lymphoma B after a biopsy was performed.

Physical examination of right breast showed a painless tumor mass with increased consistency, fixed to deep structures; the overlying skin showed an "orange peel" appearance, reddish color and retractile nipple. Mobiles and painless axillary, cervical and inguinal lymph nodes were described. The patient showed no B symptoms (high ondulatory Pel Ebstein type fever, weight loss or night sweats) or any remarkable past medical history.

Mamography revealed a subareolar heterogeneous tumor mass with a spiculated and lobular pattern and a maximum diameter of 4 $\mathrm{cm}$.

Cell blood count (CBC) and laboratory tests were normal, LDH level was $261 \mathrm{IU} / \mathrm{L}$ and 82 microglobulin was $1,4 \mu \mathrm{g} / \mathrm{ml}$. Screening tests for HIV, HCV and HBsAg were negative.

Computed tomography (CT) performed for thorax, abdomen and pelvis reveled no pathological aspects.

Breast biopsy was performed and histopathological examination revealed large islands of non-cohesive large cells, with round to oval nuclei with visible nucleoli, and high nucleus-cytoplasm ratio and a high proliferative index that effaced the breast parenchyma (Fig. 1A). The tumor showed a diffuse growth pattern with large cells which were similar immunoblasts (amphophilic cytoplasm, eccen- 


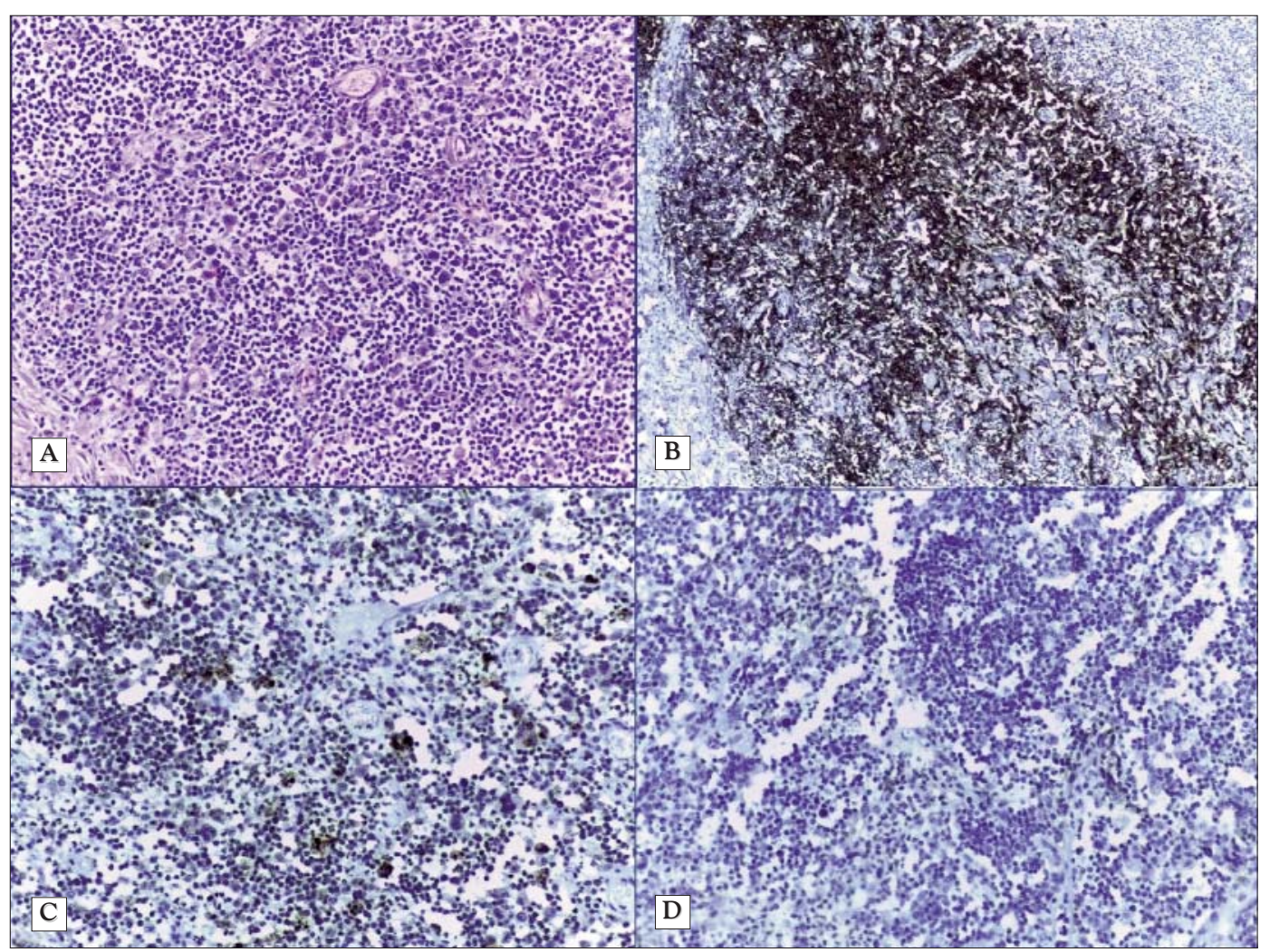

Figure 1. (A) Ob 20x: HE: Islands of non-cohesive large cells with round to oval nuclei, visible nucleoli and a high nucleus-cytoplasm ratio. (B) Ob 20x: CD20: nuclear positivity in large cells. (C) Ob 20x: CD10: nuclear positivity in large cells. D: Ob 20X: BCL6 - negative

tric nuclei with one central nucleolus) or centroblasts (pale or basophilic cytoplasm, vesicular chromatin due to chromatin margination, 2 - 3 nucleoli, often near nuclear membrane) facts highly suggestive of DLBC. Additional immunohistochemical investigations were performed to assess the phenotype and provide a definitive diagnosis. The neoplastic cells showed positivity for CD 20 (Fig. 1B), CD 10 (Fig. 1C), BCL 6 (Fig. 1D) and were negative for CK, BCL 2, myc, and ER/PR. The fraction of Ki-67-positive tumor cells was about $90 \%$. In light of the ancillary tests the final diagnosis was established as primitive breast diffuse large B cell lymphoma (PBL) stage IE according to American Joint Committee on Cancer 2010 ( $7^{\text {th }}$ edition) staging system /Ann Arbor, resulting in classification as early stage by definition. A right Madden type mastectomy with axillary lymph node dissection was the surgical choice.

Postoperatory microscopic examination of the surgical specimen revealed the same aspects as anterior biopsy with the same immunohistochemical profile, no malignant cells in axilary lymph nodes.

An osteomedullary biopsy showed a negative result for lymphomatous infiltration.

The patient received 3 cycles of $\mathrm{R}$-CHOP chemotherapy and immunotherapy and the left thoracic wall was irradiated with prophylactic total dose of $50 \mathrm{~Gy}$, in 10 fractions. Follow-up CT and PET CT after 6 cycles of R-CHOP imunochemotherapy highlighted absence of any residual tumor.

Follow-up chest CT and breast ultrasonography (USG) performed 17 months after radiotherapy revealed that no morbidities (such as radiation pneumonitis or arm edema) occurred. 


\section{Discussions}

The rarity of this type of breast malignancy is explained by the fact that histologically, the breast parenchyma contains less lymphoid tissue than other organs such as small or large intestines where primary lymphomas are more frequently found. (5)

The definition of PBL was for the first time proposed by Wiseman and Liao in 1972 in a study that included only a small number of patients: (1) a pathological specimen with a close association between the lymphomatous infiltrate and the breast tissue; (2) extramammary lymphoma or a widespread disease; (3) Primary tumor with in the mammary gland and ipsilateral lymph nodes simultaneous. Because of the rarity of the disease, most of the previous studies were small retrospective analyses. $(6,7)$ So primitive breast lymphoma (PBL) with large B cells was defined as unilateral or bilateral localized extranodal breast lymphoma without the importance of the regional lymph nodes. (8)

The most common type of primary breast lymphoma is diffuse large B cell lymphoma. The right breast was involved in our case. PBL occurs more frequently in the right breast, with a $3: 2$ ratio, according to literature data $(6,9,10)$.

Breast ultrasound features of tumoral mass were heterogeneous, ill defined. Because none of these imaging features are pathognomonic, a biopsy was necessary. Not only a histopathological examination but also immunohisto-chemical staining were mandatory for diagnosis.

No consensus exists on the best way to treat PBL. Miller et al concluded that three cycles of CHOP regimen followed by IFRT (involvedfield radiation therapy) are superior to eight cycles of chemotherapy alone (11). Nowadays, the most common chemotherapeutic regimen for treating $\mathrm{PBL}$ is $\mathrm{R}-\mathrm{CHOP}$ with rituximab, a monoclonal antibody targeting the CD 20 antigen which is reported to have a high efficacy for DLBCL. (12) Rituximab, lumpectomy, and three cycles of chemotherapy are recommended as treatment options. However, further studies are necessary to validate this treatment protocol (13).

Mastectomy has been a common PBL therapy for decades and remains a frequent treatment choice in some reports $(14,15)$. Studies regarding surgery by Ryan et al, showed that mastectomy was associated with increased risk of mortality, as opposed to biopsy or lumpectomy. In addition, axillary node dissection did not show any improvement in survival $(10,16)$.

Diagnosis was made by core needle biopsy and staged by computed tomography scans of the chest, abdomen and pelvis and bone marrow biopsy. The staging and histopathological diagnosis was based on the Ann Arbor staging system and WHO nomenclature $(9,17)$.

\section{Conclusions}

Here we report an extremely rare case of PBL in a male patient, confirmed by histopathology and immunohistochemistry and treated with Madden type mastectomy and axillary lymph node dissection associated with $\mathrm{R}-\mathrm{CHOP}$ and radiotherapy. Six respective seventeen months follow-up showed complete response (clinical, biological, hematological and imagistic evaluation).

Clinical and imagistic examinations of PBL are not different from breast carcinoma. , Although chemo and immunotherapy seems to be the more typical choice, alone or in combination with other treatments there are not clear consensus concerning the therapy.

The histological subtype, disease extent and the individual patient represents the base of chemotherapeutic choice.

Conflict of Interests: none declared.

\section{Contribution of Authors}

All authors have equally contributed to this work.

\section{Ethical Policies}

We undersigned, certificate that the procedures and the experiments we have done respect the 
ethical standards in the Helsinki Declaration of 1975 , as revised in 2000 , as well as the national law.

\section{References}

1. Jinming X, Qi Z, Xiaoming Z, Jianming T. Primary non-Hodgkin's lymphoma of the breast: mammography, ultrasound, MRI and pathologic findings. Future Oncol. 2012;8(1):105-9. doi: 10.2217/fon.11.132

2. Caon J, Wai ES, Hart J, Alexander C, Truong PT, Sehn LH, et al. Treatment and outcomes of primary breast lymphoma. Clin Breast Cancer. 2012;12(6):412-9. doi: 10.1016/j.clbc.2012.07.006. Epub 2012 Sep 25.

3. Avenia N, Sanguinetti A, Cirocchi R, Bistoni G, Trastulli S, D'Ajello F, et al. Primary breast lymphomas: a multicentric experience. World J Surg Oncol. 2010;8:53. doi: 10.1186/1477-7819-8-53.

4. Mouna B, Saber B, el Tijani H, Hind M, Amina T, Hassan E. Primary malignant non-Hodgkin's lymphoma of the breast: a study of seven cases and literature review. World J Surg Oncol. 2012;10:151. doi: 10.1186/1477-7819-10-151.

5. Ferguson DJ. Intrepithelial lymphocytes and macrophages in the normal breast. Virchows Arch A Pathol Anat Histopathol. 1985; 407(4):369-78.

6. Yang H, Lang RG, Liu FF, Wang XF, Jin ZJ, Lü AJ, et al. Primary lymphoma of breast: a clinicopathologic and prognostic study of 40 cases. Zhonghua Bing Li Xue Za Zhi. 2011;40(2):79-84. Chinese

7. Wiseman C, Liao KT. Primary lymphoma of the breast. Cancer. 1972;29(6):1705-12.

8. Yhim HY, Kang HJ, Choi YH, Kim SJ, Kim WS, Chae YS, et al.
Clinical outcomes and prognostic factors in patients with breast diffuse large B cell lymphoma; Consortium for Improving Survival of Lymphoma (CISL) study. BMC Cancer. 2010;10:321. doi: 10.1186/1471-2407-10-321.

9. Yang H, Lang RG, Liu FF, Wang XF, Jin ZJ, Lü AJ, et al. Primary lymphoma of breast: a clinicopathologic and prognostic study of 40 cases. Zhonghua Bing Li Xue Za Zhi. 2011;40(2):79-84. Chinese

10. Uesato M, Miyazawa $Y$, Gunji $Y$, Ochiai T. Primary non-Hodgkin's lymphoma of the breast: report of a case with special reference to 380 cases in the Japanese literature. Breast Cancer. 2005;12(2): 154-8.

11. Miller TP, Dahlberg S, Cassady JR, Adelstein DJ, Spier CM, Grogan TM, et al. Chemotherapy alone compared with chemotherapy plus radiotherapy for localized intermediate- and high-grade nonHodgkin's lymphoma. N Engl J Med. 1998;339(1):21-6.

12. Coiffier B. Rituximab therapy in malignant Iymphoma. Oncogene. 2007;26(25):3603-13.

13. Sun Y, Joks M, Xu LM, Chen XL, Qian D, You JQ, et al. Diffuse large B-cell lymphoma of the breast: prognostic factors and treatment outcomes. Onco Targets Ther. 2016;9:2069-80. doi: 10.2147/ OTT.S98566. eCollection 2016.

14. Ganjoo K, Advani R, Mariappan MR, McMillan A, Horning S. NonHodgkin lymphoma of the breast. Cancer. 2007;110(1):25-30.

15. el-Ghazawy IM, Singletary SE. Surgical management of primary lymphoma of the breast. Ann Surg. 1991;214(6):724-6.

16. Jennings WC, Baker RS, Murray SS, Howard CA, Parker DE, Peabody LF, et al. Primary breast lymphoma: the role of mastectomy and the importance of lymph node status. Ann Surg. 2007; 245(5):784-9.

17. Avilés A, Delgado S, Nambo MJ, Neri N, Murillo E, Cleto S. Primary breast lymphoma: results of a controlled clinical trial. Oncology. 2005;69(3):256-60. Epub 2005 Sep 15. 